\title{
ANALYSIS OF LAND USE AND LAND COVER MAPS SUITABILITY FOR MODELING POPULATION DENSITY OF URBAN AREAS - REDISTRIBUTION TO NEW SPATIAL UNITS BASED ON THE OBJECT CLASSIFICATION OF RAPIDEYE DATA*
}

\author{
Tomasz Pirowski \\ AGH University of Science and Technology, \\ Faculty of Mining Surveying and Environmental Engineering \\ Małgorzata Timek \\ AGH University of Science and Technology, \\ Faculty of Mining Surveying and Environmental Engineering \\ Katarzyna Wietrzykowska, M.Sc. \\ Ericsson sp. z o. o
}

Keywords: population data, dasymetric modeling, OBIA, RapidEye

\begin{abstract}
The series of articles contains a comparison of the use of information on building zones from three sources for dasymetric population mapping: from the Corine Land Cover project (CLC), from the Urban Atlas project (UA) and from the object classification (OBIA) of the RapidEye data. These sources are characterized by varying spatial and thematic accuracy as well as a different methodology of building separation. The experiment was carried out in the area of Kraków, using statistical data from 141 urban units (u.u.) of the city.

In the first part of the cycle, population conversions were presented based on the Corine Land Cover (CLC) and Urban Atlas (UA) databases. The second part presents the methodology of mapping construction zones, divided into several categories, by means of object classification (OBIA). The classifications were carried out on four RapidEye satellite images. The developed map is the basis for the population calculation in three variants: binary method, and two surface-weight aggregation methods, where the proportions of population density for different building categories are calculated by minimizing square error (RMSE) and percentage (MAPE) in census units. The obtained results of the population distribution indicate the need to determine the function of development. Therefore, in addition, experiments were carried out combining OBIA results with the LULC map of the UA project. From the experiments it appears that from the tested six variants of population mapping the best is the surface-weight method based on OBIA+UA (RMSE $=4,270$ people/u.u., MAPE $=75 \%$.). Binary method based on OBIA+UA results at RMSE $=4540$ people/u.u., MAPE $=108 \%$. Results with the use of OBIA, without correction of building functions with UA, are incorrect (RMSE: 5958-7987 people/u.u., MAPE: 2262\%-6612 \%).

In the subsequent parts of the publication cycle, the results obtained so far will be compared: three CLC-based maps, three UA-based maps, six maps based on OBIA/ OBIA+UA. To verify the population map, a detailed reference map of the Bronowice district will be used as well as a 1-kilometer GUS grid. A discussion will be conducted related to the use of RMSE and MAPE parameters in the process of results optimization. A ranking of methods and recommendations will be developed to improve the results of population conversion based on CLC, UA and OBIA.
\end{abstract}

* This article has been prepared within the scope of the AGH UST statutory research no. 11.11.150.949 


\title{
ANALIZA PRZYDATNOŚCI MAP POKRYCIA I UŻYTKOWANIA TERENU DO MODELOWANIA GĘSTOŚCI ZALUDNIENIA OBSZARÓW MIEJSKICH - PRZELICZANIE MAP DO NOWYCH JEDNOSTEK PRZESTRZENNYCH, OPARTYCH O KLASYFIKACJĘ OBIEKTOWA DANYCH RAPIDEYE
}

\author{
Słowa kluczowe: dane demograficzne, modelowanie dazymetryczne, klasyfikacja obiektowa, RapidEye
}

\section{Streszczenie}

Cykl artykułów zawiera porównanie możliwości wykorzystania do kartowania ludności informacji o strefach zabudowy z trzech źródeł: z projektu Corine Land Cover (CLC), z projektu Urban Atlas (UA) oraz z wyniku klasyfikacji obiektowej (OBIA) danych RapidEye. Źródła te charakteryzują się różną dokładnością przestrzenną i tematyczną oraz różną metodologią wyodrębniania zabudowy. Eksperyment przeprowadzono na obszarze Krakowa, wykorzystując dane statystyczne ze 141 jednostek urbanistycznych miasta.

W pierwszej części cyklu zaprezentowano przeliczanie populacji w oparciu o bazy danych Corine Land Cover (CLC) oraz Urban Atlas (UA). W drugiej części przedstawiono metodykę kartowania stref zabudowy, z podziałem na kilka jej kategorii, za pomocą klasyfikacji obiektowej (OBIA). Klasyfikacje przeprowadzono na czterech zmozaikowanych obrazach satelitarnych RapidEye. Opracowana mapa stanowi podstawę do dazymetrycznego przeliczenia ludności w trzech wariantach: binarnym, oraz dwóch powierzchniowo-wagowych, gdzie proporcje zagęszczenia ludności dla różnych kategorii zabudowy obliczane są poprzez minimalizację błędu kwadratowego (RMSE) i procentowego (MAPE) w jednostkach spisowych. Uzyskane wyniki rozkładu ludności wskazują na potrzebę określenia funkcji zabudowy. Dlatego dodatkowo wykonano eksperymenty łączące wyniki OBIA z mapą LULC projektu UA. Z eksperymentów wynika, że z testowanych sześciu wariantów kartowania ludności najlepszym jest metoda powierzchniowo-wagowa oparta o OBIA+UA (RMSE $=4270 \mathrm{os}$., MAPE $=75 \%$.). Metoda binarna oparta o OBIA+UA notuje wyniki na poziomie RMSE $=4540$ os., MAPE $=108 \%$ Wyniki z zastosowaniem OBIA, bez korekcji funkcji zabudowy przy pomocy UA, są błędne (RMSE: od 5958-7987os., MAPE: 2262\%-6612\%).

W kolejnych częściach cyklu publikacji zostaną porównane dotychczas uzyskane wyniki: trzy mapy oparte o CLC, trzy mapy oparte o UA, sześć map opartych o OBIA/ OBIA+UA. Do weryfikacji map populacji zostanie użyta szczegółowa mapa referencyjna dzielnicy Bronowice oraz kilometrowa siatka GUS. Przeprowadzona będzie dyskusja związana ze stosowaniem parametrów RMSE i MAPE w procesie optymalizacji wyników. Opracowany zostanie ranking metod oraz rekomendacje zmierzające do uzyskania poprawy wyników przeliczania ludności w oparciu o CLC, UA i OBIA.

\section{INTRODUCTION}

Population density maps are one of the basic cartographic studies. Thanks to the possibilities offered by GIS and the integration of data from various sources, they reflect the spatial distribution of the population more and more correctly. Until a dozen or so years ago, the most popular forms of the presentation were maps of isolines, dotted maps and simple cartograms, where the number of people per unit of surface was presented in relation to the boundaries of the administrative division (Ratajski, 1989). In recent years, this type of studies are gradually being replaced by more accurate dasymetric mapping methods. They consist in advanced disaggregation of statistical data. The process of creating the dasymetric cartogram includes additional limiting variables and variable relations, and the reference units represent the actual boundaries of the occurrence of the phenomenon.
The selection of reference units of the dasymetric cartogram assumes the homogeneity of areas (a similar intensity of a given phenomenon - for the population density map, in its simplest form, these are areas of housing development or lack thereof). Current studies are based on digital maps and databases of topographic objects providing high accuracy and automation of the mapping process. An example of the use of building information and detailed databases are the publications of Lwina and Murayama (2009), Całka et al., 2016, Pirowski and Bartos (2018), Cockx and Canters (2015). A precursor to the use of LULC data from the CLC project for population mapping is the work of Gallego and Pedel (2001). The methodology was developed in subsequent years (Gallego, 2010). Bielecka and others adapted it to domestic conditions. (2005). Then, on the Urban Atlas database, Pirowski and Pomietłows$\mathrm{ka}$ (2017). Information is also obtained directly from satellite data, generating the necessary information on 
land cover by classifying buildings in terms of population mapping (Dittakan et al 2013, Lo, 2003). The results are improved by data on the heights of buildings from laser scanning (Upegui and Viel, 2012), and detection of impervious areas accompanying buildings $(\mathrm{Wu}$ and Murray, 2005, Bajat et al., 2013). It is also looking for the correlation of the population with the spectral and textural characteristics of the multi-spectral image channels, thus avoiding classification (Harvey, 2002, Webster, 1996, Chen, 2002).

The presented surveys assess the mapping of urban development using the object classification method, in terms of its suitability for the dasymetric conversion of the population of Krakow. The redistribution of the population was carried out from 141 census statistical units of the city, from the so-called urban units (u.u.).

\section{TEST AREA, INPUT DATA}

The analysis area is within the administrative boundaries of Krakow. The total area of the city is $326.85 \mathrm{~km}^{2}$. Within it there are various forms of land use. The central part of the city is dominated by residential, commercial and service buildings. There is a dense network of streets and urban green belts. In the latitudinal system, the Vistula River runs through Kraków. Districts, agricultural areas and forest areas are an advantage in districts far from the center. In such areas of the city there is a loose or dispersed building. The eastern part of Krakow, behind the former metallurgical plant, is characterized by a very high share of land used for agriculture. In the Nowa Huta district, industrial buildings (eastern part) and housing estate (western and northern part) prevail.

Administratively, Krakow is divided into four cadastral units (Śródmieście, Krowodrza, Podgórze and Nowa Huta), whose borders coincide with the course of smaller units - eighteen districts. The names of districts usually come from the names of villages or towns that previously formed separate settlement units. In each of the districts of the city, smaller urban units and housing estates are distinguished. These are the smallest units (altogether 141) for which publicly available statistics are available. The detailed arrangement of u.u.. In the form of a map, is included in the first part of the publication cycle. Statistical information about the Krakow population was obtained from the StatKrak website (www.msip2.um.krakow.pl). The collected statistics constitute a systematized database (updated at least once a year), on three levels of detail. The most general category of „City” lists groups of statistical data: population, education, culture and art, communication, economy, municipal infrastructure, tourism, health, environment, public safety. In the categories „District” and „Urban Planning Unit”, the data are divided into: basic (population living permanently, temporarily and generally, broken down by age and gender), aggregated (population in age ranges every 5 years, economic age groups, employment) and reports - detailed statements. The analysis used data on the population living in particular urban units for permanent or temporary residence. Data from 2009 were used (thus maintaining compliance with previous CLC and UA experiments, and with RapidEye data subject to classification).

RapidEye is a constellation of five high resolution, identical satellites recording the Earth's surface in five spectral channels: three visible (Red, Green, Blue), near infrared (NIR) and Red Edge. The spatial resolution of the images is 5 meters. The constellation is able to obtain up to 6 million $\mathrm{km}^{2}$ per day, providing an average return time of one day. In 2015, the constellation was taken over by the American company Planet Labs Inc. (www.satimagingcorp.com) Red Edge is a unique band recorded by the RapidEye satellites. The channel is extremely sensitive to the chlorophyll content, which is used primarily to study the health of plants. The detailed specification of the sensor is presented in Table 1. The work involved the use of four neighboring RapidEye images made on April 25, 2009, which are combined in a mosaic and limited to the borders of Krakow.

\section{BUILDINGS MAPPING BY OBJECT CLASSIFICATION AND POPULATION REDISTRIBUTION}

OBIA (Object Based Image Analysis) is one of the methods of remote sensing analysis. The basis for the construction of a photointepressive key are in it spectral features of objects and other recognition features, such as shape, texture, surface, topology, neighborhood relations. In contrast to classical classification methods, OBIA is not based on individual image pixels, but on groups that create homogeneous segments (objects), logically conceptual, which better reflect the relations of the real world (Weih and Riggan, 2010). Object-re- 
Table 1. Parameters of the RapidEye constellation (http://www.satimagingcorp.com)

Tabela 1. Parametry konstelacji RapidEye (http://www.satimagingcorp.com)

\begin{tabular}{|c|c|c|}
\hline Number of satellites & \multicolumn{2}{|c|}{5} \\
\hline The height of the heliosynchronous orbit & \multicolumn{2}{|c|}{$630 \mathrm{~km}$} \\
\hline Spectral channels & $\begin{array}{c}\text { Blue } \\
\text { Green } \\
\text { Red } \\
\text { Red Edge } \\
\text { NIR }\end{array}$ & $\begin{array}{l}440-510 \mathrm{~nm} \\
520-590 \mathrm{~nm} \\
630-730 \mathrm{~nm} \\
690-730 \mathrm{~nm} \\
760-850 \mathrm{~nm}\end{array}$ \\
\hline Pixel size & \multicolumn{2}{|c|}{$5 \mathrm{~m}$} \\
\hline The width of the imaging belt & \multicolumn{2}{|c|}{$77 \mathrm{~km}$} \\
\hline Time return visit & \multicolumn{2}{|c|}{1 day (5.5 days in nadir) } \\
\hline Radiometric resolution & \multicolumn{2}{|c|}{12 bits } \\
\hline
\end{tabular}

lated classification is closely related to the concept of image segmentation, which is based on the separation of regions with similar texture features. Most of the objects created in this way are limited by the parameter set by the user - the scale factor (Wężyk, 2012). The classification is based on created segments, and the process itself is preceded by defining a hierarchy of classes, which can consist of one or more levels of dependence between objects (Lewiński, 2007).

Object-oriented classification was performed in the eCognition software, on the five-channel RapidEye mosaic (data from April 25, 2009, resolution 5m). It was planned to classify only the building itself, with its division into three categories (compact, loose and dispersed), analogous to those used for CLC and UA based methods. However, the interpretive similarities of the development with other classes caused the need to distinguish other types of coverage (a total of eight: vegetation, single buildings, uncovered soil, roads and tracks, water, compact buildings, loose buildings, dispersed buildings). The classification was performed using the assign class method - separating each class individually, with the conditions that meet the candidate segments. The first two classes were separated from the lower level segments $(\mathrm{sp}=50)$, six more from the higher level $(s p=200)$. During the process, new parameters were defined on the basis of map algebra and relations with neighboring segments and lower-level segments (in order to use them as additional variables conditioning class membership). The classification uses vegetation and soil indexes. By using a special criterion determining the density of buildings (the ratio of the number of small segments of the building class to the total number of pixels of a large segment) three types of building were distinguished: compact, when the parameter exceeded 0.8 , loose in the range $0.3-0.8$, and dispersed for less than 0.3 . The classification scheme is shown in Fig. 1.

The diversification of buildings into three classes (Figure 2) enabled the implementation of multi-variant dasymetric maps of the population, similarly to previously realized through the use of CLC and UA databases. The procedure for estimating weights for surface-to-weight methods was carried out by minimizing the noted errors of RMSE and MAPE in the language. The methodology was analogous, as described in the first article. The calculations were carried out iteratively, in a spreadsheet, in the solver module. In the case of minimizing the MAPE error, negative weights were obtained, therefore, boundary conditions were applied, assigning a scattered development to a minimum of $0.2 \%$ of the city population (a similar procedure was performed on the CLC and UA maps). In total, three maps were obtained: binary, surface-to-weight with minimization of RMSE and surface-to-weight with minimization of MAPE.

The main problem of building classification is the lack of its division due to functions, i.e. residential and other buildings. This results in the redundancy of housing areas on the maps, especially in the industrial 


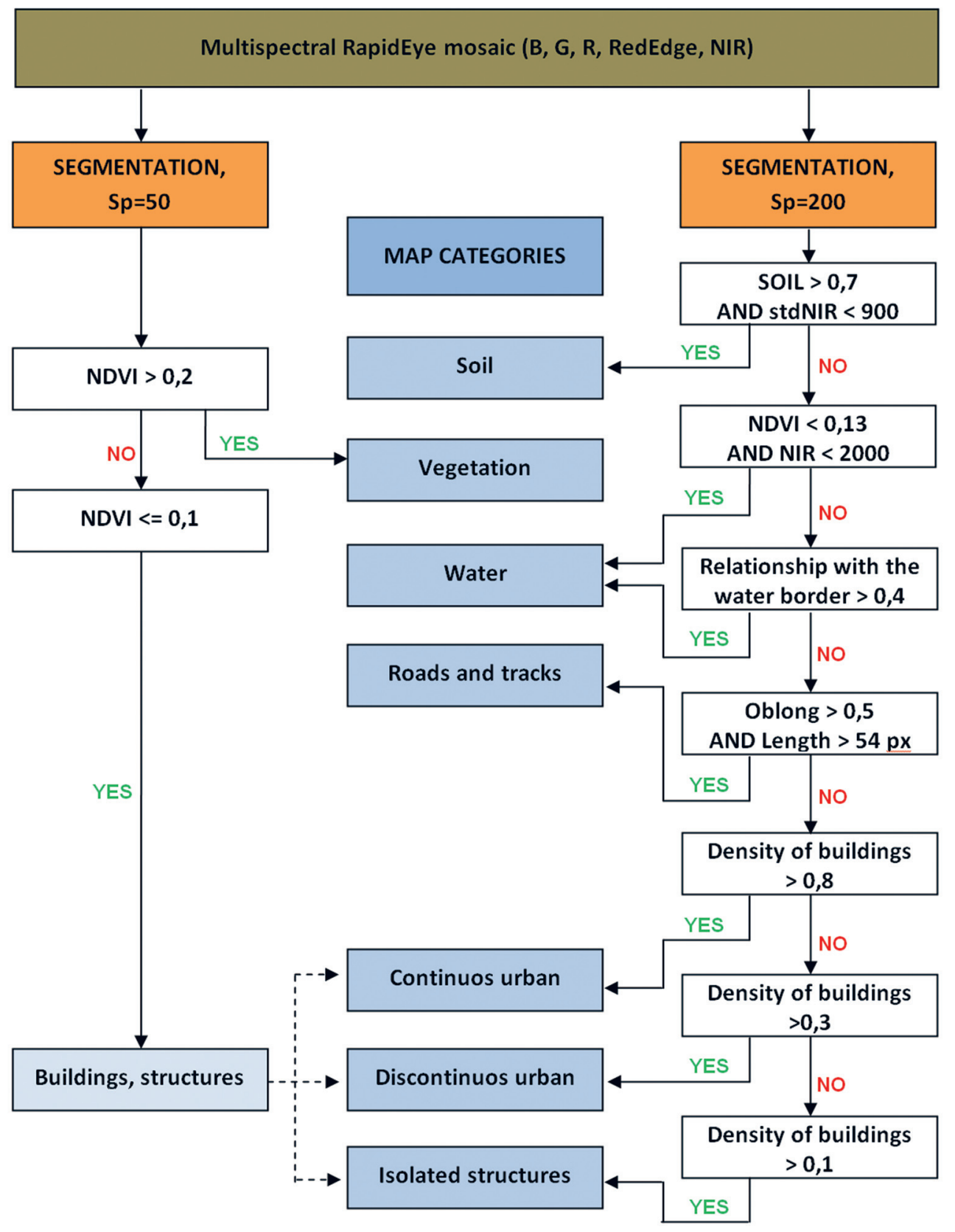

Fig. 1. Scheme of object classification used in the conducted research

Rys. 1. Schemat klasyfikacji obiektowej zastosowany w prowadzonych badaniach

and service areas of the city. This type of defect can have a significant impact on the correctness of population mapping. Therefore, it was decided to experiment to confirm these assumptions. With the help of data from Urban Atlas, only those building areas with OBIA that were included or overlapped with the UA residential area were selected. On such prepared data, analyzes for three variants were repeated. In total, six maps based on OBIA / OBIA+UA were obtained. Calculated weights for individual land cover categories are presented in table 2 .

Calculated weights allow to develop the first stage of generating population maps, where Tobler's condition (Tobler, 1979), that is, the preservation of popula- 


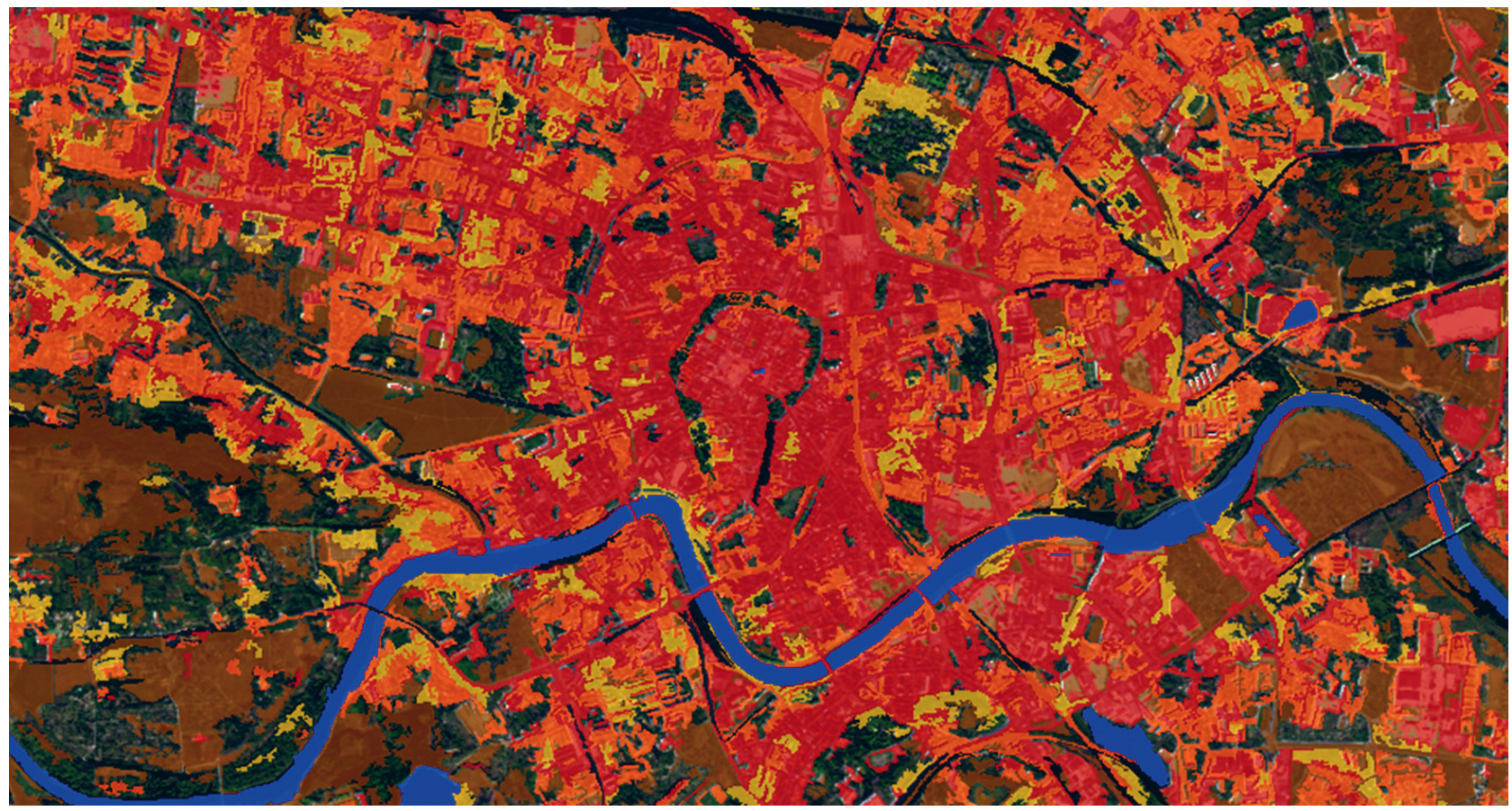

Fig. 2. OBIA classification of the central part of the city against the background of the RapidEye painting: continuos urban $t$ (red), discontinuos urban (orange) and dispersed (yellow)

Rys. 2. Klasyfikacja OBIA centralnej części miasta na tle obrazu RapidEye: zabudowa zwarta (czerwona), luźna (pomarańczowa) i rozproszona (żółta)

Table 2. The population density calculated for various options, in [people/ha]

Tabela 2. Obliczone dla różnych wariantów wartości zagęszczenie ludności, w [os./ha]

\begin{tabular}{|c|c|c|c|c|c|c|c|}
\hline \multirow[t]{2}{*}{ LULC } & \multirow{2}{*}{$\begin{array}{l}\text { Adopted categories } \\
\text { for population } \\
\text { redistribution }\end{array}$} & $\begin{array}{l}\text { binary } \\
\text { method }\end{array}$ & $\begin{array}{c}\text { min. } \\
\text { RMSE }\end{array}$ & $\begin{array}{c}\text { min. } \\
\text { MAPE }\end{array}$ & $\begin{array}{c}\text { binary me- } \\
\text { thod }\end{array}$ & $\begin{array}{l}\text { min. } \\
\text { RMSE }\end{array}$ & $\begin{array}{c}\text { min. } \\
\text { MAPE }\end{array}$ \\
\hline & & \multicolumn{3}{|c|}{ before Tobler's condition } & \multicolumn{3}{|c|}{ when the condition Tobler u.u. } \\
\hline \multirow{3}{*}{ OBIA } & I - continuos urban & \multirow{3}{*}{107,8} & 2,7 & 0,4 & \multirow{3}{*}{$0,01-463,6$} & $0,0009-25,4$ & $0,0001-177,6$ \\
\hline & II - discontinuos urban & & 305,0 & 0,6 & & $0,1-2884,5$ & $0,0002-305,0$ \\
\hline & III - isolated structures & & 3,9 & 1925,2 & & $0,0012-36,6$ & $0,73-41874,6$ \\
\hline \multirow{3}{*}{$\begin{array}{c}\text { OBIA } \\
+ \\
\text { UA }\end{array}$} & I - continuos urban & \multirow{3}{*}{200,9} & 291,0 & 393,8 & \multirow{3}{*}{$22,6-813,9$} & $37,6-1282,3$ & $59,4-2238,5$ \\
\hline & II - discontinuos urban & & 139,4 & 36,4 & & $17,9-614,4$ & $5,5-207,0$ \\
\hline & III - isolated structures & & 5,8 & 5,8 & & $0,75-17,7$ & $0,9-25,9$ \\
\hline
\end{tabular}

tion volume, is only met for the whole city. The RMSE and MAPE errors noted at this stage are summarized in Figure 3.

The last stage is the correction of the population volume in each of the u.u. to the values from statistical data, while maintaining the proportion (weight) in population density for individual building categories. The resulting maps, in the raster form, are presented in Fig. 4. The raster resolution is $5 \mathrm{~m}$, and the population is expressed in [people/ha]). 

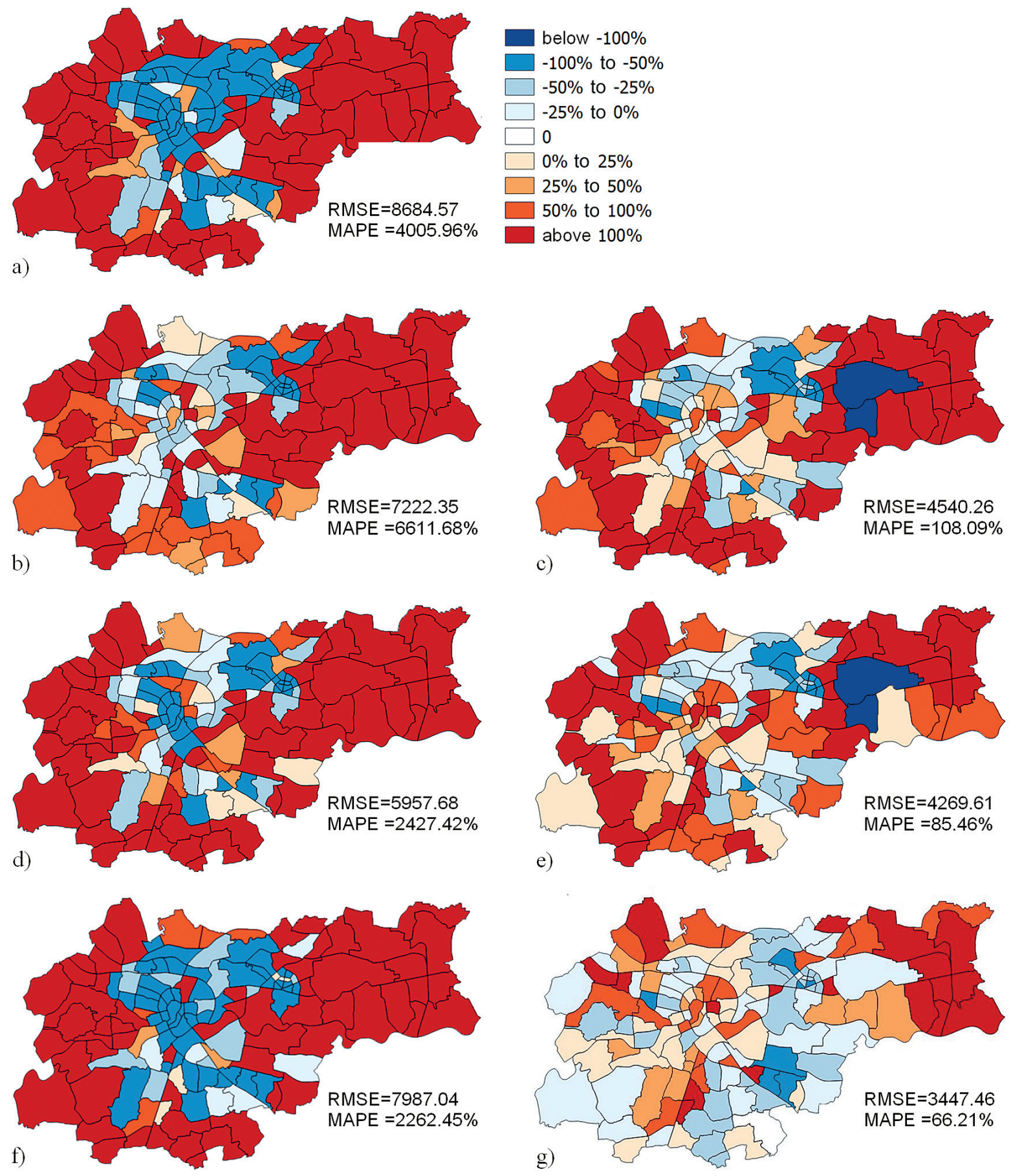

Fig. 3. Percentage errors in urban units for population maps implementing the Tobler condition for the whole city, based on: a) simple cartogram; b) OBIA (binary method); c) OBIA+UA (binary method); d) OBIA (minimization of RMSE in u.u.); e) OBIA+UA (minimization of RMSE in u.u.); f) OBIA (MAPE minimization in u.u.); g) OBIA+UA (minimization of MAPE in u.u.). RMSE expressed in people / u.u.

Rys. 3. Błędy procentowe w jednostkach urbanistycznych dla map populacji realizujących warunek Toblera dla całego miasta, opartych o: a) kartogram prosty; b) OBIA(metoda binarna); c) OBIA+UA (metoda binarna); d) OBIA (minimalizacja RMSE w j.u.); e) OBIA+UA (minimalizacja RMSE w j.u.); f) OBIA (minimalizacja MAPE w j.u.); g) OBIA+UA (minimalizacja MAPE w j.u.). RMSE wyrażony w osobach/j.u. 

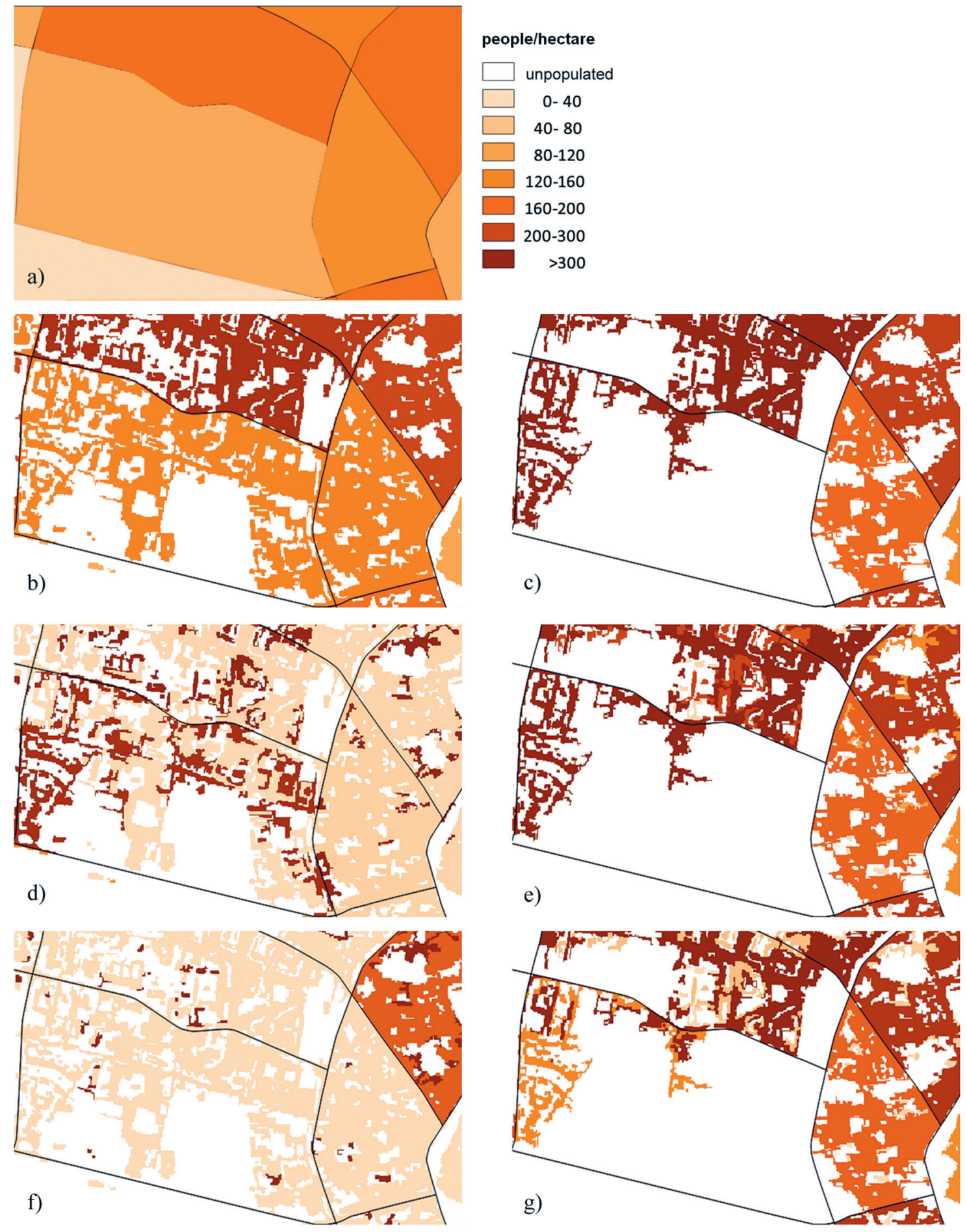

Fig. 4. Dasymetric maps of Krakow - a fragment of the center: a) simple cartogram; b) OBIA (binary method); c) OBIA+UA (binary method); d) OBIA (minimization of RMSE in u.u.); e) OBIA+UA (minimization of RMSE in u.u.); f) OBIA (MAPE minimization in u.u.); g) OBIA+UA (minimization of MAPE in u.u.)

Rys. 4. Dazymetryczne mapy Krakowa - fragment centrum: a) kartogram prosty; b) OBIA (metoda binarna); c) OBIA+UA (metoda binarna); d) OBIA (minimalizacja RMSE w j.u.); e) OBIA+UA (minimalizacja RMSE w j.u.); f) OBIA (minimalizacja MAPE w j.u.); g) OBIA+UA (min. MAPE w j.u.) 


\section{DISCUSSION}

As in the first part of the article series, the analysis of the results at this stage is preliminary (there is no reference to independent reference data). Mutual comparison of population maps and an attempt to rank them according to reliability is based on the analysis of the correctness of the separation of building zones, as well as the results of statistical estimation of population density weights for the classification of various types of buildings distinguished in the process. This can be done complementarily using information about:

- values of ,weights” assigned to buildings (analysis in Table 2, columns: „before Tobler condition"), calculated in the iterative process of minimizing RMSE and MAPE errors;

- scope and scale of the extent of absolute changes in population density values for individual building categories used to implement the Tobler condition in each of the units (analysis table 2);

- distribution of percentage errors in u.u. at the stage of weight estimation (analysis of Fig. 3, columns in Table 2: , when the condition Tobler u.u..”);

- average errors obtained for the full set of 141 items (RMSE and MAPE parameters given in Fig. 3 for particular variants);

- visual interpretation of the developed dasymetric maps (analysis of Fig. 4).

1. In Figure $3 \mathrm{a}$ it is easy to notice that relying on the adoption of the same value of population density for the entire city results in a large underestimation of the population in the broadly understood city center. On the outskirts of the city there is a reverse phenomenon (its large overestimation). It is easy to predict for Krakow (and most agglomerations in Poland), where the spatial structure of the city associated with its inhabitants is characterized by a strict, often historical center, surrounded by newer housing estates and suburban and rural suburbs, where former villages, administratively absorbed by the city, they still often retain their original character with the dominant scattered buildings, despite the progressing process of urbanization. The use of a limiting variable in the process of population conversion has, as the basic task, to diversify the share of buildings in relation to the total area. In the surface-weight method, it additionally has a differ- entiated diversification in terms of intensity and function. Through the OBIA method, the implementation of both tasks is uncertain. Separated building areas are difficult to associate with the volume of the people living in it. This can be seen through a very divergent level of error elimination depending on the variant (Fig. 3b-g): in some cases the improvement is doubtful (Fig. 3b, 3f).

2. Decrease of RMSE and MAPE and distribution of errors in u.u. it is relatively small for methods based only on OBIA (decrease in RMSE from 8685 people to 5958 , MAPE from $4006 \%$ to $2262.45 \%$ ). For these variants, there is still a large overestimation of the population in external u.u. cities. For the center, the improvement is noted only for the binary method (Fig. 3b) and with the minimization of the RMSE error (Fig. 3c).

3. A clear improvement occurs for methods where the OBIA development has been adjusted, excluding industrial and commercial areas based on the UA. RMSE results are falling to 4540 people (binary method) and 4,270 people (surface-to-weight method). For MAPE errors of an order of magnitude lower than for variants only from OBIA, i.e. $108 \%$ and $75 \%$ respectively, are recorded. As you can see, the use of building segmentation improves the parameters to a small extent. Therefore, it seems crucial to eliminate the uninhabitable areas from the process of mapping buildings using the OBIA method. The division of residential buildings itself is secondary, although its purposefulness is confirmed by the recorded decrease in errors. Visual analysis of the error distribution shows that in the binary method lower errors are obtained for central u.u. Using surface-weight methods, it is better to convert the population in u.u. outskirts of the city. This is especially visible for the method based on MAPE, where the overestimation of population in this area of the city is clearly falling in other variants. It is worth noting that the visible two u.u. in the Nowa Huta district, with a large relative undervaluation (over 100\%), they are characteristic for all variants of OBIA+UA. In absolute terms, however, the differences are small. Calculated maps attribute the lack of population in this region - in fact, according to statistical data, only a dozen or so people live there. 
4. Detailed analysis of assigned weights (Table 2), confirms the analysis based on Fig. 3. The calculated parameters of weights for variants based on OBIA are incorrect. For example: the assigned values of population density for compact building are more than 100 times lower (!) Than for loose buildings. This type of error is not noted for the OBIA+UA variants, where the calculated compaction ratios seem realistic, although difficult to confirm without additional reference data. The difference between the surface-and-weight methods of OBIA+UA (Fig. 3e, 3g) is related to the greater variation in weights. In the variant with RMSE minimization, compact housing is attributed to around $2 \mathrm{x}$ higher population density than loose housing, whereas for the variant with MAPE minimization, this multiplicity increases to about eleven. This manifests itself in a greater diversification in absolute values of the assigned population for particular building categories. This can be seen, for example, on the map from Fig. $4 \mathrm{~g}$.

5. Comparing the obtained population maps, it can be clearly seen that mapping buildings only on the basis of OBIA (Figures $4 \mathrm{~b}, 4 \mathrm{~d}, 4 \mathrm{f}$ ) yields incorrect results. The areas detected as built-up areas are mostly not inhabited. This is confirmed by the large surface reduction of buildings on maps corrected by UA (Fig. 4c, 4e, 4g). The consequence of bad building mapping is the incorrect operation of the optimization algorithm, which results in the assignment of unbelievable weights. It is easy to see this effect in practice when converting populations in Figures $4 \mathrm{~d}$ and 4f. There, for individual enclaves of loose buildings, the majority of the population of a given area is assigned. At the same time, the compact building area is up to two orders of magnitude smaller. The results from OBIA+UA, in relation to the results from OBIA, are characterized by a different surface distribution of population (the abovementioned large reduction of general building area), other density values (reduction of area automatically affects the absolute values of the population), and also their other is mutual diversification (reversal of the proportion of density for compact housing and setting them at a real level).
6. Optimization of weights by minimizing RMSE and MAPE errors is stable and similar for maps based on OBIA+UA (Fig. 3e and 3g, Fig. 3e, 3g). However, two developed maps based on OBIA are completely different, despite meeting the minimization conditions (Fig. $3 \mathrm{~d}$ and $3 \mathrm{f}$, Fig. $4 \mathrm{~d}, 4 \mathrm{f})$. This is also confirmed by the analysis of population density parameters summarized in Table 2.

\section{CONCLUSIONS}

The correct separation of housing zones (binary method) is crucial for the possibility of a reliable application of the dasymetric method of population conversion. It is also important to distinguish between different construction categories that can be related to the number of people living in it (surface-weight method). In the case of tests, this condition is met only by maps based on OBIA+UA. For such data, the use of automated weighing methods to minimize RMSE or MAPE errors can yield acceptable results. The final maps obtained for the OBIA variants, the RMSE / MAPE values, and the especially calculated values of population density for individual building categories do not reflect reality. It shows two things: (1) the separation of buildings and its category by the OBIA method is unreliable in order to connect them with population density; (2) the methodology for the selection of weights implements the criterion of minimizing errors also on erroneous data on coverage of the area, this objective is obtained through so-called the equifinality phenomenon (where global results may seem correct, by when they are locally wrong).

The biggest problem of object classification is the inability to effectively isolate residential areas from other types of buildings and impermeable areas. It is possible, however, to improve the number of precipitations using the additional data in the OBIA classification process. For example, the numerical model of land cover allows you to exclude surfaces such as parking lots, roads, bridges, squares. However, the biggest disadvantage of OBIA is the lack of the possibility to reliably distinguish the functions of the building. Therefore, it is not possible in the automatic OBIA approach to distinguish residential buildings from industrial, commercial or service. It is also difficult to implement interpretatively. However, based on additional materials possible to carry out, which 
is reflected on the UA map. Indirect confirmation finds this when the results for OBIA+UA are improved.

The perceived problem of incorrect population mapping has detected a limitation of the surface-to-weight method for the search for weights for particular construction categories based on statistical parameters and their optimization (here: minimization of RMSE, MAPE). As you can see, it is possible to reduce errors globally, but the analysis of the correctness of the result must then be based on a subjective assessment of the final parameters and the obtained maps. In the case of results from OBIA, the calculated parameters were unacceptable, making the error easy to detect. However, the question arises how to assess the correctness of the limiting variables and variable relationships used? When can they be regarded as so reliable that one can estimate ,weights" on their basis and thus correctly convert populations? Answers to these questions will be implemented in the subsequent parts of the cycle. The analysis of results using two sets of independent reference data, with different scales of detail, should give an answer to the doubts raised here.

\section{REFERENCES}

Bajat, B., Krunić N., Samardžić Petrović M., Kilibarda M. (2013). Dasymetric modeling of population dynamics in urban areas, Geodetski vestnik, Vol. 57, No. 4. DOI: 10.15292/ geodetski-vestnik.2013.04.777-792

Bielecka E., Kuczyk A., Witkowska E. (2005). Modelowanie powierzchni statystycznej przedstawiającej gęstość zaludnienia $w$ Polsce przy pomocy metody dozymetrycznej. Polskie Towarzystwo Informacji Przestrzennej, Roczniki Geomatyki, T. III, Z. 2, 9-16

Całka B., Bielecka E., Zdunkiewicz K. (2016). Redistribution population data across a regular spatial grid according to buildings characteristics, Geodesy and Cartography;| Vol. 65, no. 2, pp. 149-162

Cockx K., Canters F. (2015). Incorporating spatial non-stationarity to improve dasymetric mapping of population. Applied Geography, Vol. 63, s. 220-230

Chen, K. (2002). An Approach to Linking Remotely Sensed Data and Areal Census Data. International Journal of Remote Sensing, 23(1):37-48

Dittakan K., Coenen F., Christley R., Wardeh M. (2013). Population Estimation Mining Using Satellite Imagery. DaWaK 2013: Data Warehousing and Knowledge Discovery pp. 285-296, ISBN 978-3-642-40130-5. DOI https://doi. org/10.1007/978-3-642-40131-2_25

Gallego F.J., Peedell S. (2001). Using CORINE Land Cover to map population density. Towards agri-environmental indicators. EEA Topic report 6/2001, 94-105
Gallego F.J. (2010). A population density grid of the European Union. Population and Environment, Volume 31, Number 6, July 2010, pp. 460-473(14)

Harvey J. (2002). Estimating Census District Populations from Satellite Imagery: Some Approaches and Limitation, International Journal of Remote Sensing 23(10):2071-2095

Lewiński S. (2007). Obiektowa klasyfikacja zdjęć satelitarnych jako metoda pozyskiwania informacji o pokryciu $i$ użytkowaniu ziemi. IGiK, Warszawa. ISBN 978-83-60024-10-2; oai:bc.igik.edu.pl:21

Lo, C.P. (2003). Zone-Based Estimation of Population and Housing Units from Satellite-Generated Land Use/Land Cover Maps, in Remotely Sensed Cities, Mesev, V. (ed.), London, UK/New York, NY: Taylor \& Francis, 157-180

Lwin, K., Murayama, Y. (2009). A GIS Approach to Estimation of Building Population for Micro-spatial Analysis. Transactions in GIS 13(4), 401-414. DOI: 10.1111/j.14679671.2009.01171.x, Source: DBLP

Pirowski T., Bartos K. (2018). Detailed mapping of the distribution of a city population based on information from the national database on buildings. Geodetski vestnik, 62 (3), 458-471. DOI: http://dx.doi.org/10.15292/geodetski-vestnik.2018.03.458-471

Pirowski T., Pomietłowska J. (2017). Distribution of Krakow's Population by Dasymetric Modeling Method Using Urban Atlas and Publicly Available Statistical Data, Geomatics and Environmental Engineering, vol. 11/4, 83-95

Ratajski R. (1989). Metodyka kartografii społeczno-gospodarczej. Warszawa-Wrocław: m. Państwowe Przedsiębiorstwo Wydawnictw Kartograficznych im. Eugeniusza Romera

Tobler, R.T. (1979). Smooth pycnophylactic interpolation for geographic regions. Journal of The American Statistical Association 74, 519-530

Upegui E., Viel J.-F. (2012). GeoEye imagery and Lidar Technology for small-area population estimation: an epidemiological viewpoint. Photogrammetric Engineering \& Remote Sensing, Vol. 78, s. 693-702

Webster, C.J. (1996). Population and Dwelling Unit Estimation from Space. Third World Planning Review, 18(2):155-176

Weih R.C., i Riggan N.D., 2010. Object-based classification vs. Pixel-based classification: Comparitive importance of multi-resolution imagery. The International Archives of the Photogrammetry, Remote Sensing and Spatial Information Sciences, Vol. XXXVIII-4/C7

Wężyk P., Wójtowicz-Nowakowska A., Pierzchalski M., Most J., Szwed P. (2012). Klasyfikacja pokrycia terenu metoda OBIA $z$ wykorzystaniem zobrazowań satelitarnych RapidEye. Archiwum Fotogrametrii, Kartografii i Teledetekcji, Vol. 23, s. 489-500; ISSN 2083-2214 | ISBN 978-83-61576-19-8

Wu, C. and Murray, A.T. (2005). A cokriging method for estimating population density in urban areas. Computers, Environment and Urban Systems, 29 (5), 558-579, doi:10.1016/j. compenvurbsys.2005.01.006

www.satimagingcorp.com/satellite-sensors/other-satellite-sensors/rapideye/ accessed 4.06.2018

www.msip2.um.krakow.pl/statkrak/ Web sites StatKrak, accessed 28.05.2018 